\title{
IN-VITRO STUDY ON POTENTIAL EFFICACY OF ACRIFLAVINE IN THE PREVENTION OF CONJUGATIONAL TRANSFER OF DRUG RESISTANCE IN BACTERIA
}

\author{
Tamas Das ${ }^{1}$ Bipasa Chakraborty², Raja Ray ${ }^{3}$ \\ ${ }^{1}$ Junior Resident, Department of Microbiology, Institute of Post-Graduate Medical Education and Research, Kolkata. \\ 2Demonstrator, Department of Microbiology, Burdwan Medical College, Burdwan. \\ 3Professor, Department of Microbiology, Institute of Post-Graduate Medical Education and Research, Kolkata.
}

\section{ABSTRACT}

\section{BACKGROUND}

Acquisition of new resistance in bacteria is brought into effect by a battery of gene transfer systems, among which conjugation accounts for bulk of horizontal gene transfer. Acriflavine is a DNA-intercalating agent with plasmid curing properties. Since it selectively inhibits plasmid replication, it might have a role in interfering with conjugation.

The aim of this study was to observe for any in-vitro inhibitory effect of Acriflavine on horizontal transfer of resistance factors.

\section{MATERIALS AND METHODS}

Overnight BHI broth cultures of donor Escherichia coli and recipient Escherichia coli strains were taken and experiment done simultaneously in following steps. Mating between donor and recipient strain was done by broth mating protocol, and resultant transconjugant colony count (TCC) was calculated and compared between Acriflavine treated and untreated mating mixtures. The bacteriostatic effects were measured and viable colony count (VCC) was performed separately on Acriflavine treated and untreated broth cultures of both donor and recipient. Standard plasmid curing protocol using Acriflavine was performed on donor strain and curing efficacy were calculated. Five repetitions were done for each conjugating pair, and median values were used for further analysis by descriptive statistics.

\section{RESULTS}

The \% decrease of TCC was greater than \% decrease attributed to combined effect of bacteriostasis/curing. This difference hints towards the presence of some inhibitory effects other than bacteriostasis and curing.

\section{CONCLUSION}

Acriflavine being a strong DNA-intercalating agent, perhaps has some negative effect on conjugation process which needs to be further investigated. If proven, Acriflavine \& other similar compounds will open up the possibility of being used as adjuvant therapy along with antimicrobial agents to slow down the rate of development of new resistance and increased longevity of antibiotic efficacy.

\section{KEYWORDS}

Acriflavine, Conjugation, DNA Intercalation, Plasmid, R Factor, Plasmid Curing.

HOW TO CITE THIS ARTICLE: Das T, Chakraborty B, Ray R. In-vitro study on potential efficacy of Acriflavine in the prevention of conjugational transfer of drug resistance in bacteria. J. Evolution Med. Dent. Sci. 2017;6(78):5540-5546, DOI: $10.14260 /$ jemds/2017/1204

\section{BACKGROUND \\ Bacterial resistance to antimicrobials is an inevitable outcome of relentless antibiotic use and its selection is a naturally occurring and continuous phenomenon. This has become a major threat in control of infectious disease worldwide. One way to tackle this situation is by justified and rational use of antibiotics and creation of newer generation of antibiotics which work via novel mechanisms. However, it is a time consuming and costly process. Another alternative way would be by prevention of dispersal of resistance. If the spread of antimicrobial resistance (AMR) can be appropriately slowed down, then it will enhance the longevity of antibiotic usefulness and decreased dependence on reserve drugs.}

'Financial or Other Competing Interest': None.

Submission 22-08-2017, Peer Review 14-09-2017,

Acceptance 21-09-2017, Published 28-09-2017.

Corresponding Author:

Dr. Raja Ray,

A/11, Survey Park,

Santospur, Kolkata-700075.

E-mail: rjrm1175@gmail.com

DOI: $10.14260 /$ jemds $/ 2017 / 1204$
Acriflavine is an orange coloured dye, derivative of coal tar \& traditionally used as a topical antiseptic. It was introduced in World War II as a remedy for sleeping sickness. It was subsequently used for dressing burn wounds, as bladder wash, etc. It also acts as a strong DNA-intercalating agent and biotechnologists use it widely as a potent plasmid curing agent wherein a bacterium is made free of plasmids. Elimination of plasmid seems to be due to selective interference in replication of plasmid resulting in loss of entire plasmid in the newly replicated bacterium. Due to its nature of selective and specific interaction with extrachromosomal DNA, we hypothesised that it might also have some effects on conjugal transfer of plasmid-mediated resistance in bacteria. The aim of this study was to see if Acriflavine has any in-vitro inhibitory effect on horizontal transfer of resistance factors and the potential efficacy of such effect.

\section{MATERIALS AND METHODS}

Three donor Escherichia coli strains and two recipient Escherichia coli strains were collected from various sources (Table 1). Biochemical tests, antibiotic susceptibility tests, and Phenotypic Confirmatory Tests for ESBL detection were 
done following standard methods. Our experiment comprised of three parts which were performed simultaneously for each conjugating pair.

\section{Preparation of Donor and Recipient Cultures}

$0.5 \mathrm{~mL}$ of overnight BHI broth cultures of donor and recipient were added separately to $10 \mathrm{~mL}$ (achieved dilution is 1:20) of fresh BHI broth and incubated for up to 3 hours to obtain actively growing phase cultures. Approximate cell concentration to be achieved is $2 \times 10^{8} \mathrm{CFU} / \mathrm{mL}$ as checked by $\mathrm{OD}_{600}=0.08-0.1$ using spectrophotometer. ${ }^{1}$ This preparation was used as the starting source of donor and recipient in all following experiments.

\section{Experiment 1- Conjugation (by broth mating)}

$0.5 \mathrm{~mL}$ of donor and $2.5 \mathrm{~mL}$ of recipient culture was added to $10 \mathrm{~mL}$ of fresh BHI broth in a $25-\mathrm{mm}$ wide sterile test tube and mixed by gentle pipetting. ${ }^{2-4}$ This mating mixture is divided into 4 parts of $2.5 \mathrm{~mL}$ each. One would act as control (labelled C) and the others as test (labelled T1, T2, T3). In the tubes "T", Acriflavine solution was added to achieve final concentrations of $50 \mu \mathrm{g} / \mathrm{mL}, 25 \mu \mathrm{g} / \mathrm{mL}, 12.5 \mu \mathrm{g} / \mathrm{mL}$ respectively. Nothing is added to tube " $\mathrm{C}$ ". All tubes " $\mathrm{C}$ " and "T" are incubated in a slant position ${ }^{2}$ overnight at $35^{\circ} \mathrm{C}$ in dark \& ambient air. Next day, tubes marked "T" were checked for turbidity. If there was an absence of turbidity, that tube was rejected since we needed to study the effects of Acriflavine only at sub-inhibitory levels. $0.1 \mathrm{~mL}$ of culture from " $\mathrm{C}$ " is taken and diluted ${ }^{5}$ to $10^{-3} .100 \mathrm{uL}$ of this dilution was streaked onto selective BHI agar plates containing both Streptomycin (Str) $100 \mu \mathrm{g} / \mathrm{mL}+$ Cefotaxime (Ctx) $2 \mu \mathrm{g} / \mathrm{mL} .4,6$ Streaking was done using a glass rod spreader following spread plate technique. ${ }^{7}$ All these plates were incubated for 24-48 hours.

The same process is followed for " $\mathrm{T}$ " tubes too.

Successful conjugation would transfer ESBL determining plasmid from donor (Cefotaxime Resistant-Ctx ${ }^{\mathrm{R}}$ ) to recipient (Streptomycin Resistant-StrR) and the resultant product (Transconjugant) would hence be phenotypically $\operatorname{Str}^{R} \mathrm{Ctx}^{\mathrm{R}}$. Thus, a selective antibiotic plate containing Ctx+Str would selectively allow the growth of such transconjugants whereas inhibiting growth of either pure donor (since its Strs $^{S}$ ) or the recipient (since its $\mathrm{Ctx}^{\mathrm{S}}$ ). After incubation, plates were checked for growth of any transconjugants. Colonies were counted by taking a picture with digital camera and then analysing enlarged image on a computer screen. The difference in transconjugant colony count (TCC) between control and test was noted.

To crosscheck for valid plasmid transference, several random transconjugant colonies were subcultured and confirmed for ESBL using Phenotypic Confirmatory Test.

\section{Experiment -2 Plasmid Curing}

Alongside conjugation experiment, the donor strains were subjected to curing treatment ${ }^{8}$ to determine plasmid curing efficacy at conditions and concentrations used in test "T". A $10 \mathrm{~mL}$ BHI broth containing the same concentration of Acriflavine (as used in conjugation experiment above) was inoculated with $0.5 \mathrm{~mL}$ of the donor. This was incubated overnight in dark at $35^{\circ} \mathrm{C}$. And $0.1 \mathrm{~mL}$ of culture was taken and made $10^{-3}$ dilutions, then $100 \mathrm{uL}$ of this dilution was spread on BHI agar using the spread plate technique. ${ }^{7}$ This plate was incubated overnight in dark at $35^{\circ} \mathrm{C}$. For patch plating ${ }^{9}$ two $\mathrm{BHI}$ agar plates were taken -one containing no additives and other one containing antibiotic (Cefotaxime 2 $\mu \mathrm{g} / \mathrm{mL}$ or Tetracycline $30 \mu \mathrm{g} / \mathrm{mL}$ ). These plates had a circular grid template attached at the base. Each grid had a serial number. From the spread plate prepared in step 2 above, random isolated colonies were sampled using sterile toothpicks. It was then streaked on both plates at same corresponding grid numbers. About 120 random colonies were patch plated.

After overnight incubation at $37^{\circ} \mathrm{C}$, plates were observed for the cured cells. The cured plasmid cells were detected by comparing the development of bacterial colonies on antibiotic containing plate with that of the normal (Without antibiotic) plate. The samples that showed colonies on normal BHI agar but failed to grow on BHI agar supplemented with antibiotic were the possible cured isolates. ${ }^{10}$ Such suspected cured isolates were sampled from the respective grid on a normal BHI plate, and confirmed phenotypically by biochemical and antibiogram studies. ${ }^{11}$

\section{Experiment -3 Performing Viable Colony Count (VCC)}

To measure the bacteriostatic effects, viable colony count (VCC) was performed separately on Acriflavine treated and untreated broth cultures of both donor and recipient. $0.5 \mathrm{~mL}$ donor was added to $10 \mathrm{~mL} \mathrm{BHI}$ broth and divided into 4 parts of $2.5 \mathrm{~mL}$ each. Similarly, in a different test tube, $2.5 \mathrm{~mL}$ recipient was added to $10 \mathrm{~mL}$ BHI broth and then divided into 4 parts. The following steps were done on both.

In first part nothing was added and in the rest 3 parts, Acriflavine was added to achieve final concentrations of 50 $\mu \mathrm{g} / \mathrm{mL}, 25 \mu \mathrm{g} / \mathrm{mL}$, and $12.5 \mu \mathrm{g} / \mathrm{mL}$ respectively. All tubes were incubated overnight at $35^{\circ} \mathrm{C}$ in dark \& ambient air. Next day, $0.1 \mathrm{~mL}$ of culture was taken and made $10^{-3}$ dilution, then $100 \mu \mathrm{L}$ of this dilution was spread on BHI agar using the spread plate technique. Following overnight incubation, colony count was performed by taking a picture and analysing on a computer screen. VCC thus obtained was compared among Acriflavine and no-Acriflavine tubes of donor and recipient separately.

The tests were performed with 5 repetitions in each experiment set. Descriptive statistics using bar/line diagrams were used to represent median values from each data set.

\section{RESULTS}

In our conjugation experiments, there was a clear transfer of the resistance factor among all strains studied. On exposure to Acriflavine, there was a significant decrease in Transconjugant Colony Count (TCC) signifying certain inhibition of conjugation. Viable Colony Count (VCC) performed on Acriflavine treated and untreated cultures of donor and recipient (Bacteriostatic experiment) revealed a decrease in colony counts in Acriflavine treated sets. Plasmid curing was also observed in donor strains, but in insignificant numbers.

However, \% decrease of TCC was much greater than \% decrease attributed to the effects of bacteriostasis/curing. This difference may hint towards the presence of some other phenomenon which negatively affects resistance transfer. 


\begin{tabular}{|c|c|c|c|c|}
\hline \multicolumn{2}{|r|}{ Donor Strains } & $\begin{array}{l}\text { Susceptibility to } \\
\text { Streptomycin }\end{array}$ & $\begin{array}{l}\text { Susceptibility to } \\
\text { Cefotaxime }\end{array}$ & $\begin{array}{l}\text { Susceptibility to } \\
\text { Tetracycline }\end{array}$ \\
\hline D1 & $\begin{array}{l}\text { ESBL producing Escherichia coli strains collected from } \\
\text { clinical isolates at Dept. of Microbiology, IPGME\&R }\end{array}$ & Sensitive $\left(\mathrm{Str}^{\mathrm{S}}\right)$ & Resistant $\left(\mathrm{Ctx}^{\mathrm{R}}\right)$ & \\
\hline D2 & $\begin{array}{l}\text { ESBL producing Escherichia coli strains collected from } \\
\text { clinical isolates at Dept. of Microbiology, IPGME\&R }\end{array}$ & Sensitive $\left(\mathrm{Str}^{\mathrm{S}}\right)$ & Resistant $\left(\mathrm{Ctx}^{\mathrm{R}}\right)$ & \\
\hline D3 & $\begin{array}{c}\text { Escherichia coli from HiMedia X-Pert Bacterial } \\
\text { Conjugation Kit HTM004-5PR }\end{array}$ & Sensitive $\left(\mathrm{Str}^{\mathrm{S}}\right)$ & & Resistant $\left(\right.$ Tet $\left.^{\mathrm{R}}\right)$ \\
\hline \multicolumn{5}{|c|}{ Recipient Strains } \\
\hline R1 & $\begin{array}{l}\text { Genetically engineered Escherichia coli } 2443 \text { obtained } \\
\text { from Dept. Of Biotechnology, IIT Kharagpur. }\end{array}$ & Resistant $\left(\mathrm{Str}^{\mathrm{R}}\right)$ & Sensitive $\left(\mathrm{Ctx}^{\mathrm{S}}\right)$ & Sensitive $\left(\right.$ Tet $\left.^{\mathrm{S}}\right)$ \\
\hline $\mathrm{R} 2$ & $\begin{array}{l}\text { Recipient Escherichia coli from HiMedia X-Pert } \\
\text { Bacterial Conjugation Kit HTM004-5PR }\end{array}$ & Resistant $\left(\mathrm{Str}^{\mathrm{R}}\right)$ & Sensitive $\left(\mathrm{Ctx}^{\mathrm{S}}\right)$ & Sensitive $\left(\right.$ Tet $\left.^{S}\right)$ \\
\hline
\end{tabular}

\begin{tabular}{|c|c|c|c|}
\hline $\begin{array}{c}\text { Escherichia coli } \\
\begin{array}{c}\text { Screened Positive for } \\
\text { ESBL* }\end{array}\end{array}$ & $\begin{array}{c}\text { Escherichia coli Confirmed } \\
\text { Positive for ESBL by PCT } \dagger\end{array}$ & $\begin{array}{c}\text { No. of ESBL Escherichia coli } \\
\text { Sensitive to Streptomycin }\end{array}$ & $\begin{array}{c}\text { Escherichia coli which showed good } \\
\text { Conjugation Frequency with Recipient } \\
\text { strains. }\end{array}$ \\
\hline 112 & 73 out of 112 & 7 out of 73 & 2 out of 7 \\
\hline \multicolumn{2}{|c|}{ Table 2. Selection of Donor Strains from Clinical Isolates } \\
\hline
\end{tabular}

* ESBL- Extended Spectrum Beta Lactamase, †PCT- Phenotypic Confirmatory Test. All screening and confirmatory tests for ESBL detection was done following CLSI 2017 guidelines.

\begin{tabular}{|c|c|c|c|c|c|c|c|c|}
\hline \multirow{3}{*}{$\begin{array}{c}\text { Experiment } \\
\text { Pair }\end{array}$} & \multicolumn{4}{|c|}{ Transconjugant Colony Count (TCC)* } & \multicolumn{4}{|c|}{ Change in TCC with Respect to Control } \\
\hline & \multirow[b]{2}{*}{ Control } & \multirow[b]{2}{*}{$\begin{array}{l}\text { Acriflavine } \\
12.5 \mu \mathrm{g} / \mathrm{mL}\end{array}$} & \multirow[b]{2}{*}{$\begin{array}{c}\text { Acriflavine } 25 \\
\mu \mathrm{g} / \mathrm{mL}\end{array}$} & \multirow[b]{2}{*}{$\begin{array}{c}\text { Acriflavine } 50 \\
\mu \mathrm{g} / \mathrm{mL}\end{array}$} & \multicolumn{2}{|c|}{ Acriflavine $12.5 \mu \mathrm{g} / \mathrm{mL}$} & \multicolumn{2}{|c|}{ Acriflavine $25 \mu \mathrm{g} / \mathrm{mL}$} \\
\hline & & & & & $\begin{array}{c}\text { Absolute } \\
\text { Change }\end{array}$ & $\begin{array}{c}\% \\
\text { Change }\end{array}$ & $\begin{array}{c}\text { Absolute } \\
\text { Change }\end{array}$ & $\begin{array}{c}\% \\
\text { Change }\end{array}$ \\
\hline $\mathrm{D} 1+\mathrm{R} 1$ & 659 & 537 & 479 & $x$ & 122 & 18.51 & 180 & 27.31 \\
\hline $\mathrm{D} 1+\mathrm{R} 2$ & 742 & 569 & 510 & $x$ & 173 & 23.32 & 232 & 31.27 \\
\hline $\mathrm{D} 2+\mathrm{R} 1$ & 427 & 338 & 314 & $x$ & 89 & 20.84 & 113 & 26.46 \\
\hline $\mathrm{D} 2+\mathrm{R} 2$ & 478 & 372 & 331 & $x$ & 106 & 22.18 & 147 & 30.75 \\
\hline $\mathrm{D} 3+\mathrm{R} 1$ & 616 & 481 & 434 & $x$ & 135 & 21.92 & 182 & 29.55 \\
\hline $\mathrm{D} 3+\mathrm{R} 2$ & 743 & 574 & 508 & $x$ & 169 & 22.75 & 235 & 31.63 \\
\hline
\end{tabular}

* Data is representative of the median value among 5 repetitions for each pair $\times$; there was no appreciable turbidity, hence this tube was not processed further

\begin{tabular}{|c|c|c|c|c|c|c|c|}
\hline \multirow{3}{*}{ Experiment Pair } & \multicolumn{3}{|c|}{ Donor Viable Colony Count (VCC)* } & \multicolumn{4}{|c|}{ Change in Donor VCC with respect to Control } \\
\hline & \multirow[b]{2}{*}{ Control } & \multirow{2}{*}{$\begin{array}{c}\text { Acriflavine } 12.5 \\
\mu \mathrm{g} / \mathrm{mL}\end{array}$} & \multirow{2}{*}{$\begin{array}{c}\text { Acriflavine } 25 \\
\mu \mathrm{g} / \mathrm{mL}\end{array}$} & \multicolumn{2}{|c|}{ Acriflavine $12.5 \mu \mathrm{g} / \mathrm{mL}$} & \multicolumn{2}{|c|}{ Acriflavine $25 \mu \mathrm{g} / \mathrm{mL}$} \\
\hline & & & & $\begin{array}{c}\text { Absolute } \\
\text { change }\end{array}$ & $\%$ Change & $\begin{array}{l}\text { Absolute } \\
\text { change }\end{array}$ & $\%$ Change \\
\hline $\mathrm{D} 1+\mathrm{R} 1$ & 1602 & 1365 & 1294 & 237 & 14.79 & 308 & 19.22 \\
\hline $\mathrm{D} 1+\mathrm{R} 2$ & 1670 & 1421 & 1344 & 249 & 14.91 & 326 & 19.52 \\
\hline $\mathrm{D} 2+\mathrm{R} 1$ & 1840 & 1601 & 1526 & 239 & 12.98 & 314 & 17.06 \\
\hline $\mathrm{D} 2+\mathrm{R} 2$ & 1306 & 1133 & 1081 & 173 & 13.24 & 225 & 17.22 \\
\hline $\mathrm{D} 3+\mathrm{R} 1$ & 1645 & 1450 & 1367 & 195 & 11.85 & 278 & 16.89 \\
\hline D3+R2 & 1800 & 1551 & 1479 & 249 & 13.83 & 321 & 17.83 \\
\hline
\end{tabular}

* Data is representative of the median value among 5 repetitions for each donor strain. 


\begin{tabular}{|c|c|c|c|c|c|c|c|}
\hline \multirow{3}{*}{ Experiment Pair } & \multicolumn{3}{|c|}{ Recipient Viable Colony Count (VCC)* } & \multicolumn{4}{|c|}{ Change in Recipient VCC with respect to Control } \\
\hline & \multirow[b]{2}{*}{ Control } & \multirow{2}{*}{$\begin{array}{c}\text { Acriflavine } 12.5 \\
\mu \mathrm{g} / \mathrm{mL}\end{array}$} & \multirow[b]{2}{*}{ Acriflavine $25 \mu \mathrm{g} / \mathrm{mL}$} & \multicolumn{2}{|c|}{ Acriflavine $12.5 \mu \mathrm{g} / \mathrm{mL}$} & \multicolumn{2}{|c|}{ Acriflavine $25 \mu \mathrm{g} / \mathrm{mL}$} \\
\hline & & & & $\begin{array}{c}\text { Absolute } \\
\text { Change }\end{array}$ & $\%$ Change & $\begin{array}{c}\text { Absolute } \\
\text { Change }\end{array}$ & $\%$ Change \\
\hline $\mathrm{D} 1+\mathrm{R} 1$ & 1936 & 1622 & 1523 & 314 & 16.21 & 413 & 21.33 \\
\hline $\mathrm{D} 1+\mathrm{R} 2$ & 1401 & 1157 & 1102 & 244 & 17.37 & 299 & 21.34 \\
\hline $\mathrm{D} 2+\mathrm{R} 1$ & 1635 & 1369 & 1282 & 266 & 16.26 & 353 & 21.59 \\
\hline $\mathrm{D} 2+\mathrm{R} 2$ & 1450 & 1198 & 1135 & 252 & 17.37 & 315 & 21.72 \\
\hline D3+R1 & 1503 & 1267 & 1170 & 236 & 15.70 & 333 & 22.15 \\
\hline $\mathrm{D} 3+\mathrm{R} 2$ & 1503 & 1254 & 1174 & 249 & 16.56 & 329 & 21.88 \\
\hline
\end{tabular}

* Data is representative of the median value among 5 repetitions for each recipient strain.

\begin{tabular}{|c|c|c|c|}
\hline Acriflavine & $\begin{array}{l}\text { No. of Random Colonies } \\
\text { Selected for Screening }\end{array}$ & $\begin{array}{l}\text { No. of Colonies which were } \\
\text { Sensitive to Cefotaxime } \\
\text { (cured)* }\end{array}$ & $\begin{array}{c}\text { Curing \% } \\
=\frac{\text { No of CFUs cured }}{\text { Total No of CFU's tested }} \times 100\end{array}$ \\
\hline \multicolumn{4}{|c|}{ Plasmid curing of D1 (on day of conjugating D1+R1) } \\
\hline Acriflavine $12.5 \mu \mathrm{g} / \mathrm{mL}$ & 120 & 1 & $0.83 \%$ \\
\hline Acriflavine $25 \mu \mathrm{g} / \mathrm{mL}$ & 120 & 3 & $2.50 \%$ \\
\hline \multicolumn{4}{|c|}{ Plasmid curing of D1 (on day of conjugating D1+R2) } \\
\hline Acriflavine $12.5 \mu \mathrm{g} / \mathrm{mL}$ & 120 & 1 & $0.83 \%$ \\
\hline Acriflavine $25 \mu \mathrm{g} / \mathrm{mL}$ & 120 & 4 & $3.33 \%$ \\
\hline \multicolumn{4}{|c|}{ Plasmid curing of D1 (on day of conjugating D2+R1) } \\
\hline Acriflavine $12.5 \mu \mathrm{g} / \mathrm{mL}$ & 120 & 1 & $0.83 \%$ \\
\hline Acriflavine $25 \mu \mathrm{g} / \mathrm{mL}$ & 120 & 2 & $1.66 \%$ \\
\hline \multicolumn{4}{|c|}{ Plasmid curing of D1 (on day of conjugating D2+R2) } \\
\hline Acriflavine $12.5 \mu \mathrm{g} / \mathrm{mL}$ & 120 & 1 & $0.83 \%$ \\
\hline Acriflavine $25 \mu \mathrm{g} / \mathrm{mL}$ & 120 & 4 & $3.33 \%$ \\
\hline \multicolumn{4}{|c|}{ Plasmid curing of D1 (on day of conjugating D3+R1) } \\
\hline Acriflavine $12.5 \mu \mathrm{g} / \mathrm{mL}$ & 120 & 1 & $0.83 \%$ \\
\hline Acriflavine $25 \mu \mathrm{g} / \mathrm{mL}$ & 120 & 2 & $1.67 \%$ \\
\hline \multicolumn{4}{|c|}{ Plasmid curing of D1 (on day of conjugating D3+R2) } \\
\hline Acriflavine $12.5 \mu \mathrm{g} / \mathrm{mL}$ & 120 & 1 & $0.83 \%$ \\
\hline Acriflavine $25 \mu \mathrm{g} / \mathrm{mL}$ & 120 & 2 & $1.67 \%$ \\
\hline
\end{tabular}

* Data is representative of the median value among 5 repetitions for each donor strain.

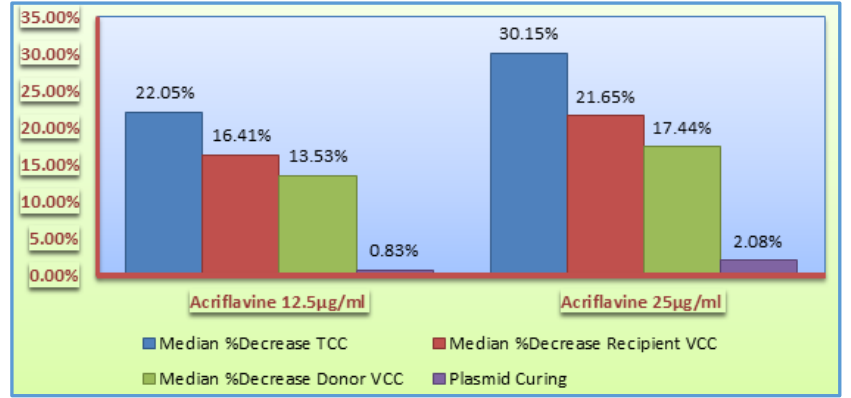

Figure 1. Representation of Final Results. Decrease in Transconjugant Colony Count (TCC) > Decrease in Viable Colony Count (VCC) and Curing

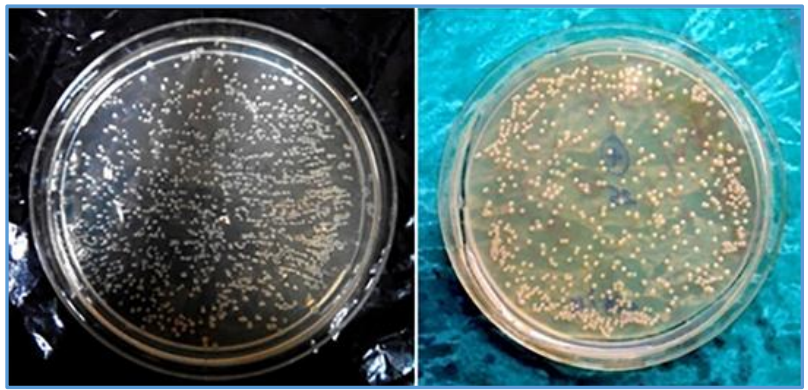

Figure 2. Spread plate of Transconjugants grown on BHI agar Containing Streptomycin + Cefotaxime. Left Image is of CONTROL PLATE - Mating Mixture Contains no Acriflavine. Right image is of TEST PLATE-Mating Mixture was treated with Acriflavine $25 \mu \mathrm{g} / \mathrm{mL}$. Number of Colonies on Test Plate is Appreciably less than that of Control Plate 

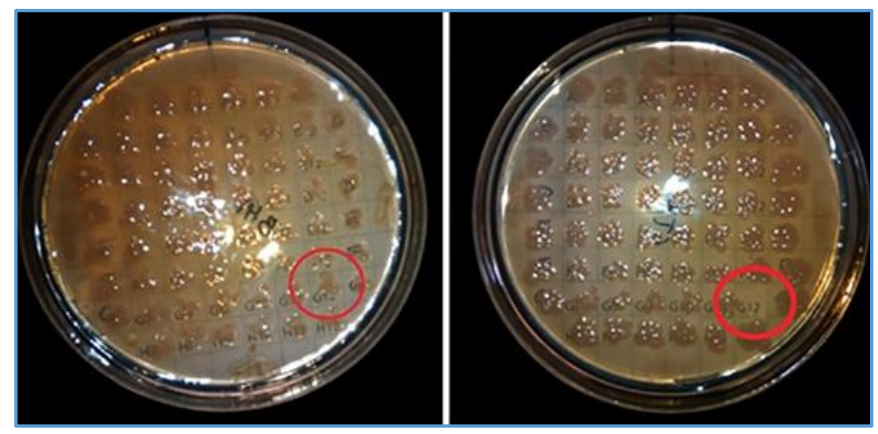

Figure 3.

Figure 3. Patch plates for detecting plasmid curing. Left marked area shows presence of growth. Right - marked area shows absence of growth. For patch plating, two plates were used in each set. One of the plates had only BHI agar (on left) and the other (on right) was BHI + Cefotaxime $(2 \mu \mathrm{g} / \mathrm{mL}$ ).

Using sterile toothpick, a random isolated colony was sampled from spread plate of Acriflavine treated donor strain, and streaked in duplicate onto the same corresponding grid numbers on both plates. Following incubation, they were compared for growth at corresponding patches on both plates. Curing of resistance marker would be represented by growth on plain BHI plate only, and absence of growth in a corresponding grid on Cefotaxime added plate. Such suspected cured isolates were sampled from respective grid on normal BHI plate, and confirmed phenotypically by biochemical and antibiogram studies.
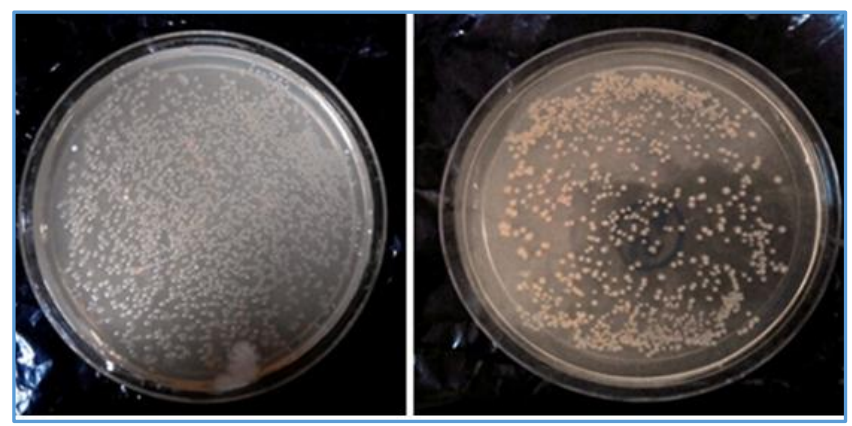

Figure 4. Spread Plates of Recipient Strain done for Viable Colony Count. Left- Control plate. Right- Test Plate with Recipient Treated with $25 \mu \mathrm{g} / \mathrm{mL}$ of Acriflavine

\section{DISCUSSION}

The explosive increase in prevalence of multidrug resistant bacteria has sparked investigation of new strategies for controlling infection. Conjugative plasmids have recently gained attention as potential targets because of the high frequency of antibiotic resistance arising from conjugation, which can be $10^{5}$ times as frequent as spontaneous chromosomal mutation conferring resistance, and indeed resistance against $\beta$-lactams and aminoglycosides has been largely spread by conjugative transfer. ${ }^{12}$ In addition, conjugative plasmids readily transmit multiple resistance genes. ${ }^{13}$ Inhibiting conjugation has been suggested as a strategy to prevent or slow the spread of antibiotic resistance genes to dangerous pathogens. ${ }^{14}$ Work in this direction has previously focused on inhibiting the apparatus involved in DNA transfer. ${ }^{15}$ One such approach is by inhibiting the conjugative DNA relaxase with bisphosphonates like clodronate and etidronate. ${ }^{15}$ Targeting similar relaxases, other compounds too have shown potential like EDTA and Sulbactomax. ${ }^{16}$ There are also reports of certain Synthetic Fatty Acids ${ }^{17}$ having selective inhibition of donors and Phage M13 ${ }^{18}$ which inhibit conjugation by other means.

Acriflavine is a well-known DNA-intercalating agent which interferes with proper DNA propagation. It has an established role as a plasmid curing agent, wherein a plasmid gets eliminated with prolonged treatment. We hypothesised that since Acriflavine has a negative influence on plasmids, maybe it could have similar negative effects on conjugational transfer too. We devised a very simple setup, wherein effect of Acriflavine was studied by analysing difference in number of transconjugants formed between Acriflavine treated and untreated mating mixture.

In selection of donor strains, we focused on ESBL strains, as studies show that ESBL determining gene is usually plasmid borne, ${ }^{19-20}$ and successful conjugation could easily be spotted by screening for transference of factors for resistance to Cefotaxime, Ceftazidime, etc. Our study too demonstrated the presence of ESBL genes on plasmids by successful conjugation in 2 out of 7 eligible donor ESBL Escherichia coli isolates (Table 2). This establishes a transferability of $28.57 \%$ which is almost in concordance with results $(30 \%-80 \%)$ of other similar studies.7,21-23 These two strains and another one (from HiMedia Kit) were further experimented to document the effects of Acriflavine.

We performed a pilot study, where Acriflavine was used at serial two-fold dilutions ( $50 \mu \mathrm{g} / \mathrm{mL}, 25 \mu \mathrm{g} / \mathrm{mL}, 12.5 \mu \mathrm{g} / \mathrm{mL}$, $6.25 \mu \mathrm{g} / \mathrm{mL}$, and $3.125 \mu \mathrm{g} / \mathrm{mL}$ ). At $50 \mu \mathrm{g} / \mathrm{mL}$, there was complete inhibition of growth. Since we wanted to see its effects at sub-inhibitory levels, this concentration was excluded from our study. At concentrations of $6.25 \mu \mathrm{g} / \mathrm{mL}$ and $3.125 \mu \mathrm{g} / \mathrm{mL}$, there were very minimal changes and clear conclusions could not be drawn from it. Hence, these particular concentrations were also excluded from our study.

In our conjugation experiments, there was successful transfer of resistance factor. With clinical isolates, donor strains transferred their ESBL bearing resistance factor to the recipient cells, thus making the latter resistant to Cefotaxime, as evidenced by antibiogram studies. Similarly, donor strain from HiMedia Kit was also able to transfer its resistance factor to the recipient, eventually making the recipient strain resistant to Tetracycline.

On exposure to Acriflavine, there was a significant decrease in Transconjugant Colony Count (TCC) signifying certain inhibition of conjugation (Table 3). At $12.5 \mu \mathrm{g} / \mathrm{mL}$ and $25 \mu \mathrm{g} / \mathrm{mL}$ of Acriflavine, the median \%reduction of TCC was $22.05 \%$ and $30.15 \%$ respectively. This decrease in TCC could have resulted from several factors such as: bacteriostatic effects of Acriflavine, plasmid curing effect on ESBL/Tet ${ }^{R}$ plasmid, or unknown direct inhibitory effect on conjugation. To document the effects of former two factors, further experiments were conducted in parallel with conjugation experiment.

Acriflavine being an antimicrobial agent has an inherent inhibitory effect on growth of bacteria 24-25 and might subsequently lead to decreased efficiency in conjugation indirectly. However, such a decrease in conjugation is only a secondary effect and does not really prove any direct action of Acriflavine in relation to conjugation. Hence, such an effect had to be quantified and compared against overall decrease of transconjugants. 
To measure growth inhibition by bacteriostasis, a Viable Colony Count (VCC) was performed on Acriflavine treated and untreated cultures of donor and recipient (Table 4,5).

In case of donors, at $12.5 \mu \mathrm{g} / \mathrm{mL}$ and $25 \mu \mathrm{g} / \mathrm{mL}$ of Acriflavine, the median \% reduction of VCC was $13.53 \%$ and $17.53 \%$ respectively. On recipients, at $12.5 \mu \mathrm{g} / \mathrm{mL}$ and 25 $\mu \mathrm{g} / \mathrm{mL}$ of Acriflavine, the median \%reduction of VCC was $16.41 \%$ and $21.65 \%$ respectively.

Acriflavine is also a DNA-intercalating agent with plasmid curing action. As studies indicate, ${ }^{26}$ plasmid curing could have potentially eliminated the resistance factor from donors and indirectly caused a decrease in conjugation frequency. Hence we needed to estimate the extent of curing action, if any. We performed plasmid curing experiments on each donor (Table 6). Median curing efficacy in our study was $0.83 \%$ and $2.08 \%$ at $12.5 \mu \mathrm{g} / \mathrm{mL}$ and $25 \mu \mathrm{g} / \mathrm{mL}$ of Acriflavine respectively. Most studies 10, 27-28 have indicated that the curing efficacy of Acriflavine is highly variable and range widely between $0-96 \%$. This is because effectiveness of curing methods depends on the nature of the bacterial host and/or plasmids where some may work better than the others. ${ }^{29}$ The extent of curing observed in our study was at the lower end of values, and less likely to have significantly affected conjugation to such a great extent.

From our experiment, we found that the \%decrease of TCC was greater than \%decrease attributed to the effects of bacteriostasis/curing. One way of explaining this imbalance would be due to the possible presence of direct inhibitory action on conjugation in addition to bacteriostatic and curing effects.

Acriflavine being a strong DNA-intercalating agent, perhaps has some negative effect on conjugation process. Studying such direct effects on conjugation requires sophisticated instruments and techniques. Such a facility was not available at our institution, hence we cannot conclusively comment on the definitive inhibitory role of Acriflavine on bacterial conjugation.

\section{CONCLUSION}

This simple study shows that Acriflavine has an overall negative effect on conjugational resistance transfer. The real mechanism still remains unexplored and warrants further study. If proved, Acriflavine and other similar compounds could be combined with existing antibiotics to formulate efficacious synergistic antimicrobial cocktails. Given the ubiquitousness of conjugative plasmids within multidrugresistant bacterial strains, it can conceivably shift the equilibrium towards success in a variety of refractory clinical infections. Superficial skin infections, which incidentally are also breeding sites of nosocomial antibiotic resistance transfer, might be effectively treated using such topical applications. They could also be used in combination with disinfectants to reduce the burden of resistant strains on contaminated surfaces. Overall, development of such compounds will help in the prevention of resistance dispersal and in extending the lifetime of our antibiotic stockpile.

\section{ACKNOWLEDGEMENTS}

We must acknowledge the fact that this research work was based upon the basic ideas and thoughts of Prof. Prasanta Kumar Maiti, Professor and Head, Department of Microbiology, IPGME\&R. This study would not have materialised without the help of Prof. Anindya S. Ghosh, Ph.D., Associate Professor, Department of Biotechnology, Indian Institute of Technology, Kharagpur, who provided us with a genetically engineered strain to conduct conjugation experiments. We are grateful to Prof Dr. Manju Banerjee, ExDirector of IPGMER for providing the facilities and her encouragement in carrying research works.

\section{REFERENCES}

[1] Mackie T, Collee J, McCartney J. Mackie and McCartney practical medical microbiology. New Delhi (India): Elsevier 2007:131-50.

[2] Cockerill F. Performance standards for antimicrobial susceptibility testing. Wayne, PA: Clinical and Laboratory Standards Institute 2013:51-2.

[3] Grinsted J, Bennett P. Methods in microbiology. London: Academic Press 1988:58-60.

[4] Ribbons D, Norris J. Methods in microbiology. London: Academic Press 1972:96-7.

[5] Banerjee M, Chakrabarti A, Acharya DP, et al. Validity of mechanism of gene transfer in the process called conjugation. Indian Journal of Experimental Biology 2000;38(2):160-6.

[6] Gupta V, Roy A, Gupta S, et al. Plasmid diversity and transferable antimicrobial drug resistance, in E.coli isolates from calf diarrhoea. Int J Curr Microbiol App Sci 2014;3(9):474-80.

[7] Rao SP, Rama PS, Gurushanthappa V, et al. Extendedspectrum beta-lactamases producing Escherichia coli and Klebsiella pneumoniae: a multi-centric study across Karnataka. J Lab Physicians 2014;6(1):7-13.

[8] The Department of Environmental Sciences, University of Toledo. Antibiotic stock and working concentrations. 2014 http://www.eeescience.utoledo.edu/Faculty/Sigler/V on_Sigler/LEPR_Protocols_files/Working\%20concent rations\%20and\%20stock\%20solutions.pdf

[9] Spread Plate. Www2.hendrix.edu. 2016. http://www2.hendrix.edu/biology/CellWeb/Techniq ues/microspread.html

[10] Chu S. Transfer of plasmid borne antibiotic resistant determinants in Escherichia coli isolated from KaoPing river. Journal of Environmental Engineering And Management 2014;17(3):225.

[11] Gantt E. Developmental and cytological methods. Cambridge: Cambridge University Press 1980.

[12] Waters VL. Conjugative transfer in the dissemination of beta-lactam and aminoglycoside resistance. Front Biosci 1999;4:D433-56.

[13] Tolmasky ME, Roberts M, Woloj M, et al. Molecular cloning of amikacin resistance determinants from a Klebsiella pneumoniae plasmid. Antimicrobial Agents and Chemotherapy 1986;30(2):315-20.

[14] Williams JJ, Hergenrother PJ. Exposing plasmids as the Achilles' heel of drug-resistant bacteria. Current Opinion In Chemical Biology 2008;12(4):389-99.

[15] Lujan SA, Guogas LM, Ragonese H, et al. Disrupting antibiotic resistance propagation by inhibiting the conjugative DNA relaxase. Proceedings of the National Academy of Sciences U S A 2007;104(30):12282-7. 
[16] Chaudhary M, Payasi A. Sulbactomax prevents antimicrobial resistance development by inhibition of conjugal transfer of F plasmids. Int J Drug Dev \& Res 2012;4(1):337-45.

[17] Getino M, Sanabria-Rios DJ, Fernandez-Lopez R, et al. Synthetic fatty acids prevent plasmid-mediated horizontal gene transfer. mBio 2015;6(5):e01032-15.

[18] Lin A, Jimenez J, Derr J, et al. Inhibition of bacterial conjugation by phage M13 and its protein g3p: quantitative analysis and model. PLoS One 2011;6(5):e19991.

[19] Brolund A, Sandegren L. Characterization of ESBL disseminating plasmids. Infectious Diseases 2015;48(1):18-25.

[20] Rawat D, Nair D. Extended-spectrum Beta-lactamases in gram negative bacteria. Journal of Global Infectious Diseases 2010;2(3):263-74.

[21] Gangoue-Pieboji J, Bedenic B, Koulla-Shiro S, et al. Extended-spectrum-beta-lactamase-producing Enterobacteriaceae in Yaounde, Cameroon. Journal of Clinical Microbiology 2005;43(7):3273-7.

[22] Mnif B, Harhour H, Jdidi J, et al. Molecular epidemiology of extended-spectrum beta-lactamaseproducing Escherichia coli in Tunisia and characterization of their virulence factors and plasmid addiction systems. BMC Microbiology 2013;13(1):147.
[23] Wang J, Stephan R, Karczmarczyk M, et al. Molecular characterization of bla ESBL- harboring conjugative plasmids identified in multi-drug resistant Escherichia coli isolated from food-producing animals and healthy humans. Frontiers in Microbiology 2013;4:188.

[24] Dale HE. Recent developments in wound antiseptics. Postgraduate Medical Journal 1946;22(246):118-21.

[25] Browning CH, Gulbransen R. The antiseptic potency of Acriflavine, with considerations on the variability of results in testing antiseptics. The British Journal of Experimental Pathology 1921;2(2):95-102.

[26] Symposium C. Bacterial episomes and plasmids. Hoboken: John Wiley \& Sons Ltd., 2009: p. 241.

[27] Bouanchaud DH, Chabbert YA. Practical effectiveness of agents curing $\mathrm{R}$ factors and plasmids. Annals of the New York Academy of Sciences 1971;182(1):305-11.

[28] Karthikeyan V, Santosh SW. Comparing the efficacy of plasmid curing agents in Lactobacillus acidophilus. Beneficial Microbes 2010;1(2):155-8.

[29] Ghosh S, Mahapatra NR, Ramamurthy T, et al. Plasmid curing from an acidophilic bacterium of the genus Acidocella. FEMS Microbiology Letters 2000;183(2):271-4. 